\title{
DEVELOPING RELIGIOUS BASED HOTS ASSESMENT BOOK IN SCIENCE SUBJECT TO INCREASE TEACHERS' COMPETENCE IN DESIGNING HOTS ASSESSMENT AT ELEMENTARY SCHOOL
}

\author{
Dwi Indah Mulyani ${ }^{1}$, Sri Utaminingsih ${ }^{2}$, Slamet Utomo ${ }^{3}$ \\ 1,2,3 Universitas Muria Kudus, Indonesia \\ 1'dwii4305@gmail.com, ${ }^{3}$ slamet.utomo@umk.ac.id
}

\begin{abstract}
The purpose of this study was to determine: 1) the development of a religious-based HOTS assessment book; 2) the effectiveness of the book to improve teachers' competence in preparing religious-based HOTS assessments for grade 4 elementary school in science subject content. This research was a development research (RnD) adapted from Borg and Gall development model with the following procedures: 1) Identification of Potentials and Problems; 2) Data Collection; 3) Product Design; 4) Design Validation; 5) Product Revision I; 6) Product Trial; 7) Product Revision II; 8). Trial Use; 9) Revision of the End Product; and 10) Product Dissemination. The product of this research was religious based HOTS assessment book in science subject content for grade IV SD. The feasibility of the book was shown through validation (material and media testing) by two material and media experts, getting an average validation score of 80.49 with very good category. The effectiveness of using books was proven by the t test which obtained t count $=-9.892<$ t table $=1.72$ so that Ha was accepted. The conclusion of this study was religious-based HOTS assessment book increased teachers ${ }^{\prime}$ competence in compiling HOTS assessments at elementary schools. Suggestions in this study included that teachers should use this HOTS-based assessment book to improve their competence in HOTS assessments.
\end{abstract}

Keywords: book, assessment, HOTS, religious

\section{PENGEMBANGAN BUKU PENILAIAN HOTS BERBASIS RELIGIUS MUATAN PELAJARAN IPA UNTUK MENINGKATKAN KOMPETENSI GURU MENYUSUN PENILAIAN HOTS DI SEKOLAH DASAR}

\begin{abstract}
ABSTRAK
Tujuan penelitian ini untuk mengetahui: 1) pengembangan buku penilaian HOTS berbasis religius; 2) keefektifitasan buku untuk meningkatkan kompetensi guru dalam menyusun penilaian HOTS berbasis religius muatan pelajaran IPA kelas 4 Sekolah Dasar. Penelitian ini merupakan penelitian pengembangan $(\mathrm{RnD})$ yang diadaptasi dari model pengembangan Borg and Gall dengan prosedur meliputi: 1) Identifikasi Potensi dan Masalah; 2) Pengumpulan Data; 3) Desain Produk; 4) Validasi Desain; 5) Revisi Produk I; 6) Uji Coba Produk; 7) Revisi Produk II; 8). Uji Coba Pemakaian; 9) Revisi Produk Akhir; dan 10) Diseminasi Produk. Hasil Penelitian: 1) Dihasilkan buku penilaian HOTS berbasis religius muatan pelajaran IPA kelas IV SD. Kelayakan buku ditunjukkan melalui validasi (uji materi dan media) oleh dua orang ahli materi dan media, memdapatkan skor rata-rata validasi 80,49 dengan kategori sangat baik; 2) Keefektifan penggunaan buku dibuktikan dengan uji t. Diperoleh $\mathrm{t}$ hitung $=-9.892<\mathrm{t}$ tabel=1.72 jatuh pada daerah penerimaan $\mathrm{H}_{2}$. Simpulan penelitian adalah penggunaan buku penilaian HOTS berbasis religius berpengaruh dapat meningkatkan kompetensi guru dalam menyusun penilaian HOTS di Sekolah Dasar. Saran dalam penelitian ini antara lain, hendaknya guru menggunakan buku penilaian HOTS berbasis ini untuk meningkatkan kompetensinya dalam penilaian HOTS.
\end{abstract}

Kata Kunci: buku, penilaian, HOTS, religius

\begin{tabular}{|c|c|c|}
\hline Submitted & Accepted & Published \\
\hline 04 September 2020 & 05 September 2021 & 16 September 2021 \\
\hline
\end{tabular}

\begin{tabular}{|l|l|r|}
\hline Citation & $:$ & $\begin{array}{r}\text { Mulyani, D.I., Utaminingsih, S., \& Utomo, S. (2021). Developing Religious Based HOTS Assesment Book in Science } \\
\text { Subject to Increase Teachers' Competence in Designing HOTS Assessment at Elementary School. Jurnal PAJAR } \\
\text { (Pendidikan dan Pengajaran), 5(5), 1369-1376. DOI : http://dx.doi.org/10.33578/pjr.v5i5.8137. }\end{array}$ \\
\hline
\end{tabular}

\section{PENDAHULUAN}

Permendiknas Nomor 16 Tahun 2007 tentang Standar Kualifikasi Akademik dan
Kompetensi Guru mata pelajaran (termasuk guru SD) dinyatakan bahwa kompetensi guru mata 
pelajaran antara lain adalah mengembangkan instrumen penilaian (Budiman, A., \& Jailani, J. 2014).

Penilaian hasil belajar diharapkan dapat membantu peserta didik untuk meningkatkan kemampuan berpikir tingkat tinggi (HOTS), karena berpikir tingkat tinggi dapat mendorong peserta didik untuk berpikir secara luas dan mendalam tentang materi pelajaran (Fanani, M. Z., 2018). Tetapi faktanya, di beberapa sekolah sampel penelitian pendahuluan, penilaian hasil belajar berorientasi HOTS yang dilakukan guru masih menemui kendala.

Penilaian berorientasi HOTS berbasis Religius merupakan dua hal yang tidak boleh dipisahkan, untuk mengetahui perkembangan peserta didik dalam hal pengetahuan, sikap dan keterampilan berpikir tingkat tinggi yang berkaitan dengan aspek-aspek religi.

Carter, McCullough, dan Carver (2012) mengemukakan hasil penelitiannya bahwa orangorang yang lebih religius cenderung untuk memantau posisi pencapaian tujuan mereka (selfmonitoring) ke tingkat yang lebih besar, yang pada gilirannya berhubungan dengan kontrol diri (self control).

Kompetensi sikap spiritual dan sikap sosial dalam kurikulum 2013 dicapai melalui pembelajaran tidak langsung (indirect teaching), yaitu melalui keteladanan, pembiasaan, dan budaya sekolah. Penumbuhan dan pengembangan kompetensi sikap dilakukan sepanjang proses pembelajaran berlangsung dan dapat digunakan sebagai pertimbangan guru dalam mengembangkan karakter siswa (Fajriyah, K., Arfilia, W., \& Singgih, A. 2017).

Selain itu penilaian yang dikembangkan oleh guru diharapkan dapat mendorong peningkatan kemampuan berpikir tingkat tinggi, meningkatkan kreativitas, dan membangun kemandirian peserta didik untuk menyelesaikan masalah (Fanani, M. Z.2018).

Penelitian ini bertujuan untuk: 1) Mengembangkan buku penilaian HOTS berbasis religius muatan pelajaran IPA kelas 4 SD; 2) Menganalisis efektifitas buku untuk meningkatkan kompetensi guru dalam menyusun perangkat penilaian HOTS berbasis religius muatan pelajaran IPA kelas 4 SD

\section{KAJIAN TEORETIS}

Ilmu Pengetahuan Alam (IPA) merupakan hasil kegiatan manusia berupa pengetahuan, gagasan, dan konsep yang terorganisir, tentang alam sekitar yang diperoleh dari pengalaman melalui serangkaian proses ilmiah (Triana, V. N. 2014). Sedangkan mata pelajaran IPA adalah program antara menemukan dan mengembangkan pengetahuan, keterampilan, sikap, dan nilai ilmiah pada siswa serta rasa mencintai dan menghargai kebesaran Tuhan Yang Maha Esa.

Kata dasar religius berasal dari bahasa latin religare yang berarti menambatkan atau mengikat. Dalam bahasa Inggris disebut dengan religi dimaknai dengan agama. Dapat dimaknai bahwa agama bersifat mengikat, yang mengatur hubungan manusia dengan Tuhan-nya.

Untuk menginspirasi guru menyusun soal-soal HOTS berbasis religius berikut karakteristik HOTS

\section{a. Mengukur kemampuan tingkat tinggi}

The Australian Council for Educational Research (ACER) menyatakan bahwa kemampuan berfikir tingkat tinggi merupakan proses : menganalisis, merefleksi, memberi argumen, menerapkan konsep pada situasi berbeda, menyusun, menciptakan. Semua hal tersebut dikaitkan dengan masalah atau hal-hal yang bersifat religius.

\section{b. Berbasis permasalahan kontekstual}

Soal-soal HOTS berbasis pada situasi nyata dalam kehidupan sehar-hari, maka soal-soal HOTS berbasis religius akan membatasi perihal implementasi ajaran agama pada kehidupan nyata. Buku penilaian HOTS sebagai media belajar guru diungkapkan Bano, V.O (2018) dalam penelitiannya. Saran untuk penelitian selanjutnya : a. Bagi guru atau pendidik IPA, setelah membaca buku modul ini diharapkan dapat menerapkan dan mengaplikasikan pengelolaan penilaian autentik dengan baik dan benar terhadap peserta didik. $b$. Bagi Kepala Sekolah, diharapkan untuk terus mengoptimalkan profesionalisme guru dalam 
pengelolaan penilaian autentik, juga bagi pendidik awam di sekolahnya. c. Bagi Dinas Pendidikan, diharapkan untuk terus melakukan upaya pengembangan profesionalitas guru atau pendidik melalui buku-buku modul sehingga membawa dampak terhadap kemandirian guru untuk membaca dan meng-up grade diri.

\section{METODE PENELITIAN}

Penelitian ini merupakan penelitian pengembangan (Research and Developmental) atau R\&D. Pada penelitian ini dilakukan adaptasi dari model pengembangan Borg \& Gall yang meliputi 10 langkah yaitu: (1) Identifikasi Potensi dan Masalah; (2) Pengumpulan Data dan Informasi; (3) Desain Produk; (4) Validasi Desain; (5) Revisi Produk I; (6) Uji Coba Produk; (7) Revisi Produk II; (8) Uji Coba Pemakaian; (9) Revisi Produk Akhir; (10) Diseminasi

Dalam penelitian R\&D ini meliputi 2 tahap penelitian yaitu tahap kualitatif dan tahap penelitian kuantitatif. Pada tahap pertama dilakukan sampai validasi desain, instrument penelitiannya adalah peneliti sendiri. Sedangkan pada tahap kedua instrumen penelitian digunakan untuk menguji efektifitas buku berdasarkan hasil pretest dan postest.

\section{HASIL DAN PEMBAHASAN}

Dari hasil wawancara, pada aspek kebutuhan buku penilaian HOTS para guru memerlukan buku yang isinya diintegrasikan dengan nilai-nilai religius yang berhubungan dengan Tuhan Yang Maha Esa dan diri sendiri dalam muatan pelajaran IPA. Pada aspek kebutuhan isi, diharapkan buku berisi langkahlangkah penyusunan soal HOTS secara praktis, disertai contoh pembuatan soal HOTS, dan latihan soal HOTS untuk siswa.

Berdasarkan hasil pengumpulan data, maka dirumuskanlah rancangan produk yang dikembangkan. Tahapan pertama dalam pengembangan ini adalah membuat prototipe berupa rancangan kasar atau skema dari produk yang akan dibuat. Rancangan yang dibuat memperhatikan aspek kelayakan dan kebutuhan guru. Pada tahap kedua yaitu melakukan pengembangan prototype dengan menyusun naskah buku penilaian HOTS berbasis religius secara keseluruhan.

Penyusunan soal HOTS peneliti fokuskan pada aspek pengetahuan. Diawali dengan menganalisis KD pada muatan pelajaran IPA kelas IV SD, sampai menulis butir soal HOTS disertai pedoman penskoran, ditunjukkan dengan alur pada gambar 1.

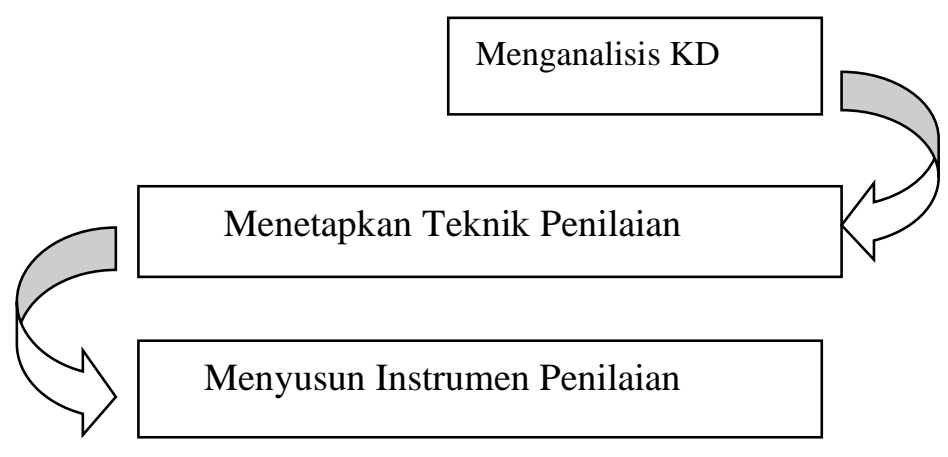

\section{Gambar 1. Alur Langkah-langkah Penyusunan Soal HOTS Berbasis Religius}

Menurut Sri Utaminingsih (2018), teknik penilaian pengetahuan adalah cara yang digunakan oleh guru untuk melakukan penilaian Kompetensi Dasar (KD) pengetahuan dengan menggunakan berbagai bentuk instrumen penilaian.Instrumen penilaian adalah alat yang disusun dan digunakan untuk mengumpulkan dan mengolah informasi untuk mengukur pencapaian hasil belajar peserta 
didik. Tehnik Penilaian pengetahuan dalam pembelajaran kurikulum 2013 terdiri tes tertulis, tes lisan dan penugasan. Tes tertulis dapat menggunakan instrumen penilaian seperti tes pilihan ganda, menjodohkan, benar salah, esay atau uraian.

Tahap ketiga, adalah tahap finishing berupa penulisan halaman pendahuluan dan penyuntingan. Halaman pendahuluan terdiri dari halaman judul, kata pengantar, daftar isi, dan daftar tabel, serta penutup.

Selesai desain dilakukan validasi produk untuk mengetahui penilaian dan validasi dari validator baik materi maupun media. Validasi produk dirancang menggunakan instrumen lembar penilaian berupa angket berskala 1-4 dan konsultasi langsung. Penilaian meliputi aspek kelayakan isi, teknik penyajian, penilaian bahasa, dan kegrafisan.

Kelayakan buku penilaian HOTS berbasis religius yang peneliti kembangkan dapat diketahui dari hasil validasi tim ahli tersebut, jika prosentase kelayakan mencapai $\geq 60 \%$ (Widoyoko 2012:111).

Adapun data hasil validasi dari tim ahli dapat dilihat pada tabel 1 .

Tabel 1. Rekapitulasi Hasil Validasi

Buku Penilaian HOTS Berbasis Religius

\begin{tabular}{|c|c|c|c|c|c|c|c|}
\hline \multirow{2}{*}{ Validator } & \multicolumn{4}{|c|}{ Aspek } & \multirow{2}{*}{ Jumlah } & \multirow{2}{*}{ Skor Rata-rata } & \multirow{2}{*}{ Kategori } \\
\cline { 2 - 5 } & Kelayakan Isi & Teknik Penyajian & Penilaian Bahasa & Kegrafisan & & & \\
\hline 1 & 91,66 & 91,66 & 79,54 & 93,75 & 356,61 & 89,15 & Sangat Baik \\
\hline 2 & 77,08 & 66,67 & 72,72 & 70,83 & 287,30 & 71,83 & Baik \\
\hline Rata-rata & 84,37 & 79,165 & 76,13 & 82,29 & & $\mathbf{8 0 , 4 9}$ & Sangat Baik \\
\hline
\end{tabular}

Berdasarkan penilaian dari tim ahli materi seperti pada tabel 1 terlihat bahwa penilaian dari semua aspek dikatakan baik sehingga buku penilaian HOTS berbasis religius layak untuk dilanjutkan pada tahap uji coba terbatas. Adapun saran dari tim ahli sebagai bahan revisi awal adalah : (1) perlu ditambahi sumber atau dalil pada unsur religius yang ada khususnya soal. (2) referensi dari tokoh penulis perlu ditambah. Secara keseluruhan terdapat 6 contoh soal HOTS yang direvisi berupa mendapat tambahan dalil yang sesuai dari $\mathrm{Al}$ Qur'an.

Setelah produk direvisi kemudian dilakukan uji coba produk pada guru kelas di SD IT Abu Bakar Ash Shidiq. Uji coba produk bertujuan untuk mengetahui penggunaan media peningkatan kompetensi pembelajaran dalam penilaian HOTS berbasis religius.

Uji coba produk dilakukan terhadap 6 guru yang dilakukan melalui teknik sampling purposive sampling, yaitu teknik penentuan sampel dengan pertimbangan tertentu (Sugiyono, 2017:124). Adapun hasil posttest pada uji coba terbatas ini rata-rata sebesar 84,44 lebih baik dari hasil ratarata hasil pretest yaitu sebesar 43.33 .

Setelah produk diujicobakan dalam uji coba terbatas atau skala kecil terhadap produk, maka selanjutnya peneliti merevisi sesuai saran dan masukan dari guru yaitu 1) Menyederhanakan bahasa yang digunakan dalam soal HOTS sehingga menjadi lebih mudah untuk dipahami dan dimengerti oleh anak usia SD khususnya kelas IV, sebagaimana tabel 2 . 
Tabel 2. Desain Revisi Produk II

\begin{tabular}{|c|c|c|}
\hline No & Awal & Revisi II \\
\hline 1 & $\begin{array}{l}\text { Allah menciptakan makhluk hidup } \\
\text { dengan sebaik-baik bentuk. Dalam } \\
\text { proses } \\
\text { pertumbuhannya, hewan juga } \\
\text { mengalami daur hidup dengan } \\
\text { berbagai bentuk sebagaimana } \\
\text { gambar di bawah ini. }\end{array}$ & $\begin{array}{l}\text { Allahlah yang menciptakan dan } \\
\text { memperkembangbiakkan makhluk } \\
\text { hidup, baik manusia dan } \\
\text { hewan (QS Luqman : 10). Dalam proses } \\
\text { pertumbuhannya, hewan mengalami } \\
\text { daur hidup } \\
\text { dengan berbagai bentuk seperti gambar } \\
\text { di bawah ini. }\end{array}$ \\
\hline 2 & $\begin{array}{l}\text { Selama masa BDR, Cantika tidak } \\
\text { lupa berolahraga setiap hari untuk } \\
\text { meningkatkan imunitas } \\
\text { tubuhnya sebagai ikhtiarnya untuk } \\
\text { menghindari virus Corona disamping } \\
\text { juga berdoa. Salah } \\
\text { satu olahraga favoritnya adalah } \\
\text { bersepeda..... }\end{array}$ & $\begin{array}{l}\text { Selama masa BDR, Cantika } \\
\text { berolahraga setiap hari untuk } \\
\text { meningkatkan imunitas } \\
\text { tubuhnya. Itu Cantika lakukan sebagai } \\
\text { ikhtiarnya untuk menghindari virus } \\
\text { Corona. Dia juga } \\
\text { tidak lupa berdoa. Salah satu olahraga } \\
\text { favoritnya adalah bersepeda.... }\end{array}$ \\
\hline 3 & $\begin{array}{l}\text { Karena kerakusan manusia (QS Al } \\
\text { Baqoroh : } 30 \text { ), bumi yang kita tinggali } \\
\text { mengalami krusakan. }\end{array}$ & $\begin{array}{l}\text { Salah satu sifat negatif manusia adalah } \\
\text { suka merusak ( QS Al Baqoroh : 30) } \\
\text { Karena sifat } \\
\text { manusia itulah, bumi yang kita tinggali } \\
\text { mengalami kerusakan. }\end{array}$ \\
\hline
\end{tabular}

Setelah revisi produk ke II, selanjutnya produk diujicobakan kepada 18 guru kelas dan 7 guru mapel terdiri dari 3 guru mapel PAI, 2 guru
PJOK, dan 1 guru Mata Pelajaran kelas bawah. Ke 24 guru sebagai sampel diatas, seluruhnya bertugas di SD IT Abu Bakar Ash Shidiq Pati.

Tabel 3. Perbandingan Skor Kompetensi Penilaian HOTS Sebelum dan Sesudah Menggunakan Buku Penilaian HOTS

\begin{tabular}{ccc}
\hline $\begin{array}{c}\text { Sebelum } \\
\text { Menggunakan }\end{array}$ & Aspek Kompetensi & $\begin{array}{c}\text { Sesudah } \\
\text { Menggunakan }\end{array}$ \\
\hline 28.70 & Pengetahuan & 80.56 \\
45.83 & Ketrampilan & 78.47 \\
\hline 37.27 & Rata-rata & 79.51 \\
\hline
\end{tabular}

Secara keseluruhan rata-rata persentase skor kompetensi penilaian HOTS pada guru yang awalnya hanya $37.27 \%$ maka setelah menggunakan buku panduam penilaian HOTS berbasis religius meningkat menjadi $79.51 \%$.

Revisi produk akhir berdasarkan hasil evaluasi dari uji pemakaian maka peneliti melakukan perbaikan produk berdasar saran dan masukan guru yaitu; 1) mengganti istilah bahasa yg kemungkinan sulit dipahami dengan istilah yang lebih mudah dipahami oleh siswa kelas 4 SD. Adapun perubahan istilah terdapat dalam tabel 3. 
Tabel 4. Revisi Produk Akhir

\begin{tabular}{ccc}
\hline No & Istilah Lama & Istilah Baru \\
\hline 1 & Imunitas & Ketahanan \\
2 & Terinspirasi & Mendapat ide \\
\hline
\end{tabular}

\section{Analisis Data}

Hasil tes hasil belajar sebagai instrument untuk mengetahui peningkatan kompetensi belajar guru dalam penilaian HOTS sebelum dan sesudah penggunaan buku penilaian HOTS berbasis religius pada muatan pelajaran IPA kelas $4 \mathrm{SD}$, dari 24 sampel guru yang diambil dengan random sampling di SDIT Abu Bakar Ash Shidiq.

Terdapat perbedaan rata-rata yang signifikan dari data responden antara sebelum dan sesudah penggunaan buku penilaian HOTS berbasis religius, yaitu 35.56 menjadi 79.72 .

Untuk membuktikan signifikansi perbedaan tersebut, diuji secara statistik dengan analisis t-test berkorelasi (sampel related), untuk mengetahui efektivitas penggunaan buku penilaian HOTS berbasis religius.

Analisis dengan menggunakan bantuan software SPSS sehingga diperoleh harga - harga yang diperlukan untuk menghitung t. Untuk membuat keputusan, apakah perbedaan signifikan atau tidak, maka harga $t$ hitung perlu dibandingkan dengan harga t tabel.

\section{Pembahasan}

Pengembangan buku penilaian HOTS brbasis religius diawali dari penelitian pendahuluan pada beberapa guru sekolah dasar di JSIT Kabupaten Pati melalui wawancara terbuka. Dari wawancara tersebut, diketahui masih minimnya pemahaman guru dalam melakukan penilaian berorientasi HOTS. Senada dengan penelitian I Wayan Merta, dkk (2019) bahwa bapak ibu guru di SMP Rayon 7 Mataram belum memahami dengan baik teknik membuat instrumen soal HOTS.

Pengetahuan dan ketrampilan tentang membuat instrumen soal HOTS untuk guru dapat dilakukan secara mandiri melalui buku ataupun modul sebagaimana penelitian berjudul "Pengembangan Modul Pelatihan Pengelolaan
Penilaian Autentik Guru IPA SMP", yang dilakukan oleh Vidriana Oktoviana Bano, dalam sarannya a. Bagi guru atau pendidik IPA, setelah membaca buku modul ini diharapkan dapat menerapkan dan mengaplikasikan pengelolaan penilaian autentik dengan baik dan benar terhadap peserta didik (Bano, V.O, 2018)

Berdasarkan wawancara lanjutan, bahwa terdapat kebutuhan adanya integrasi nilai-nilai religius pada instrumen penilaian pembelajaran untuk penanaman dan penguatan karakter siswa. Senada dengan hasil penelitian Sutono, S., \& Anif, S. (2016). Pembelajaran IPA berbasis integrasi IPA dan agama telah mampu mengembangkan nilai nilai karakter siswa kelas V SD Negeri Karangasem 2 Surakarta.

Buku penilaian HOTS yang peneliti kembangkan memuat langkah-langkah praktis yang langsung diterapkan pada muatan pelajaran IPA kelas 4 Sekolah Dasar. Langkah-langkah penyusunan soal-soal HOTS menurut I Wayan Merta (2016); dan Kemendikbud (2017, p.23): 1. Menganalisis KD yang dapat dibuat soal-soal HOTS 2. Menyusun kisi-kisi soal 3. Memilih stimulus yang menarik dan kontekstual 4. Menulis butir pertanyaan sesuai dengan kisi-kisi soal 5 . Membuat pedoman penskoran (rubrik) atau kunci jawaban.

Dari analisis KD pada Muatan Pelajaran IPA kelas IV Sekolah Dasar ternyata hanya ada 3 KD yaitu 3.1, 3.2 dan 3.4 yang tingkat kognitifnya berada pada $\mathrm{C} 4$. kemudian dilanjutkan menyusun kisi-kisi soal berbasis religius. Menurut Sri Utaminingsih (2018), membuat kisi-kisi sebelum menyusun soal bertujuan agar dapat membuat soal yang representaif mewakili KD yang akan diukur. Kisi-kisi penulisan soal-soal HOTS juga bertujuan untuk membantu para guru dalam menulis butir soal HOTS. Secara umum, kisi-kisi tersebut diperlukan untuk memandu guru dalam: a. memilih KD yang dapat dibuat soal-soal HOTS, b. memilih 
materi pokok yang terkait dengan KD yang akan diuji, c. merumuskan indikator soal, dan $d$. menentukan level kognitif.

Berdasar uraian di atas, muatan kisi-kisi peneliti kembangkan, terdiri dari $\mathrm{KD}$, Materi, Indikator Soal, Level Kognitif, Bentuk Soal, No Soal dan Nilai Religius.

Disamping adanya langkah praktis juga terdapat contoh-contoh soal yang lebih banyak terdapat dalam BAB V Kumpulan Soal HOTS Berbasis Religius, sebagaimana saran dari penelitian Poerwanti Hadi Pratiwi, dkk (2017) saran dari mahasiswa calon guru agar contohcontoh soal HOTS lebih diperbanyak.

\section{Efektifitas}

Keefektifan penggunaan buku penilaian HOTS didapatkan dari pengujian dengan eksperimen yaitu membandingkan efektifitas sebelum menggunakan buku penilaian HOTS berbasis religius dengan setelah menggunakannya. Indikator efektifitas setelah menggunakan buku penilaian HOTS berbasis religius adalah pemahaman guru terhadap konsep HOTS dan ketrampilan menyusun soal HOTS meningkat (Sugiyono, 2017:415). Peningkatan diukur melalui hasil tes (pretes postes)

Buku penilaian HOTS berbasis religius yang dihasilkan efektif dengan bukti hasil tes mengerjakan 15 soal pilihan ganda pada uji coba produk yang dilakukan oleh 6 guru. Adapun hasil postest pada uji coba terbatas rata-rata sebesar 84,44 lebih baik dari hasil rata-rata hasil pretest yaitu sebesar 43,33.

Keefektifan buku juga dapat dilihat dari perbandingan hasil pretes dan postes pada uji coba pemakaian. yang dilakukan pada 24 guru pada aspek pengetahuan dan ketrampilan. Pada aspek pengetahuan sebelum menggunakan buku penilaian HOTS berbasis religius diperoleh nilai rata-rata pretes 28,70 , setelah menggunakan buku terjadi peningkatan menjadi 80,56 . Sedangkan pada aspek ketrampilan dari 45,83 menjadi 78,47.

Dengan demikian dapat dikatakan terbukti adanya buku penilaian HOTS berbasis religius muatan pelajaran IPA dapat meningkatkan kompetensi guru menyusun penilaian HOTS di sekolah dasar.
Uji efektifitas diketahui melalui langkah analisis data hasil pretes guru saat sebelum menggunakan buku penilaian HOTS dan hasil postes setelah guru menggunakan buku penilaian HOTS berbasis religius. Dengan menggunakan bantuan software SPSS dengan uji t sampel related, didapatkan nilai t hitung $=-9.892<\mathrm{t}$ tabel $=1,72$, sehingga jatuh pada penerimaan $\mathrm{H}_{\mathrm{a}}$ atau $\mathrm{H}_{0}$ ditolak.

\section{SIMPULAN DAN REKOMENDASI}

Hasil dari penelitian ini adalah sebuah buku penilaian HOTS berbasis religius muatan pelajaran IPA kelas IV, yang terdiri dari Bagian Awal (Cover, Kata Pengantar, dan Daftar Isi); Bagian Isi yaitu Bab I Pendahuluan, Bab II Konsep Penilaian, Bab III Pengembangan dan Penyusunan Soal HOTS, Bab IV Langkah menyusun Soal HOTS Berbasis Religius, Bab V Kumpulan Soal HOTS Berbasis Religius Muatan Pelajaran IPA Kelas IV SD; Bagian Akhir (Penutup dan Daftar Pustaka).

Efektifitas produk berupa buku penilaian HOTS terbukti melalui uji t paired sample related harga $\mathrm{t}$ hitung $=-9.892<\mathrm{t}$ tabel $=1,72$ jatuh pada penerimaan $\mathrm{H}_{a}$ atau $\mathrm{H}_{0}$ ditolak. $\mathrm{H}_{0}$ ditolak sehingga disimpulkan efektivitas buku penilaian HOTS berbasis religius terhadap kompetensi pembelajaran dalam penilaian HOTS lebih baik dari sebelum penggunaan buku penilaian HOTS berbasis religius dapat diterima. Diharapkan guru dapat menggunakan buku penilaian HOTS berbasis religius muatan IPA untuk meningkatkan pemahaman dan ketrampilannya dalam menyusun penilaian HOTS di Sekolah Dasar.

\section{DAFTAR PUSTAKA}

Bano, V. O. (2018). Pengembangan Modul Pelatihan Pengelolaan Penilaian Autentik Guru IPA SMP. Kelola: Jurnal Manajemen Pendidikan, 5(2): 139-151.

Budiman, A., \& Jailani, J. (2014). Pengembangan Instrumen Asesmen Higher Order Thinking Skill (HOTS) Pada Mata Pelajaran Matematika SMP Kelas VIII Semester 1. Jurnal Riset Pendidikan Matematika, 1(2), 139-151.

DeWall, C. N., Pond Jr, R. S., Carter, E. C., McCullough, M. E., Lambert, N. M., 
Fincham, F. D., \& Nezlek, J. B. (2014). Explaining the relationship between religiousness and substance use: Selfcontrol matters. Journal of personality and social psychology, 107(2), 339.

Fajriyah, K., Arfilia, W., \& Singgih, A. (2017). ANALISIS ASESMEN BERBASIS HIGHER ORDER THINKING SKILL PADA PEMBELAJARAN TEMATIK TERPADU DI SEKOLAH DASAR. -

Fanani, M. Z. (2018). Strategi Pengembangan Soal Hots Pada Kurikulum 2013. Edudeena, 2(1), 20-25.

Kemdikbud, B. (2017). Panduan Penulisan Soal 2017 SD/MI. Pusat Penilaian Pendidikan.

Merta, I. W., Lestari, N., \& Setiadi, D. (2019). Teknik Penyusunan Instrumen Higher Order Thinking Skills (Hots) Bagi GuruGuru Smp Rayon 7 Mataram. Jurnal Pendidikan dan Pengabdian Masyarakat, 2(1), 20-27.

Pratiwi, P. H., Hidayah, N., \& Martiana, A. (2017). Pengembangan modul mata kuliah penilaian pembelajaran sosiologi berorientasi HOTS. Cakrawala Pendidikan, (2), 39-50.

Sugiyono. (2017). Metode Penelitian Pendidikan. Bandung : PT. Alfabeta.

Triana, V. N. (2014). Peningkatan Kemandiriandan Prestasi Belajar IPA Materi Energi Panas Dan Bunyi Melalui Metode Inkuiridi Kelas IV SD Negeri 1 Pamijen. Jurnal Ilmiah Pendidikan Dasar, 1(1), 32-48.

Utaminingsih, S. (2019). Penilaian Pembelajaran Tematik Berbasis HOTS (Higher Order Thinking Skills). 